\title{
Evaluation of Dietary Habits Among University Students in Konya, Turkey
}

\author{
Gulcin Algan Ozkok \\ Vocational School of Health Sciences Child Development Program, Selcuk University, Konya, Turkey
}

\section{Email address:}

gulcin8751@hotmail.com

To cite this article:

Gulcin Algan Ozkok. Evaluation of Dietary Habits Among University Students in Konya, Turkey. International Journal of Nutrition and Food Sciences. Vol. 4, No. 4, 2015, pp. 431-438. doi: 10.11648/j.ijnfs.20150404.13

\begin{abstract}
University students are the first post-childhood group who reach adulthood. A new period begins in the nutrition of students as they, following the start of education, have become more open to external factors and begin to make their own choices more explicitly. New forms that might emerge in dietary habits will be continued after university education. This study is considered helpful in the issues of encouraging adequate and balanced diet in the youth of higher education and enhancing, developing and extending dietary conditions at universities and dormitories. This study was conducted to determine dietary habits of university students aged 17-35. Data in the study was collected through questionnaire forms from a total of 310 students selected using simple random sampling. The amount of energy taken in through diet is $2075.9 \pm 965.85 \mathrm{kcal} / \mathrm{day}$ in male students and $1681.6 \pm 865.36 \mathrm{kcal} /$ day in female students. It was found that majority of the students skipped a meal and $16.8 \%$ of the students ate three main meals. Based on gender, the difference was found statistically significant between the intakes of vitamin B12, biotin, carbohydrate $(\mathrm{g})$, vitamin B2 and zinc, pantothenic acid, folate $(\mathrm{p}<0.01)$, B1, iron and phosphor $(\mathrm{p}<0.05)$ as well as protein $(\mathrm{g})$. It was discovered that the intake of vitamin $\mathrm{K}$ and phosphor by sample group exceeded $2 / 3$ RDA. In general, it was seen that there were inequalities between genders in the use of varied food items and a deficiency was detected particularly in the intake of niacin, folate, calcium, iron (in females) and magnesium. To conclude, it was found that students do not have enough knowledge of adequate and balanced diet.
\end{abstract}

Keywords: University Student, Dietary Habits, Food Intake Frequency

\section{Introduction}

Nutrition is quite significant for university students as well as it is for all levels of society. Before university education, students' dietary habits shape according to eating habits of their family, but their life style changes when they begin university and this can also change their dietary habits. Changing dietary habits affect the physical and mental condition of the youth, which has an indirect effect on their school performance (1). When young people's dietary habits and patterns are examined, it is seen that they generally skip meals, especially breakfast and lunch; they consume a lot of snack and prefer take-away fast food; they don't eat enough fruit and vegetable and as a result of this nutrient diversity is limited and unbalanced; nutritional components consist of pulp, insufficient vitamins and minerals, energy, salt, fat and simple carbohydrates (2). Studies indicated that first-year students and students who stay at dormitory are in a critical period in terms of fat intake and weight gain (3). Most of the university students form a habit of consuming high calorie foods with high fat or sugar rate and low-fiber rate. These habits can have harmful consequences in long term (4). Studies conducted on dietary habits of university students in Turkey revealed that they have serious problems about nutrition; they usually don't pay attention to their diet and sometimes they skip meals, mainly breakfast; they consume bagel and tea and they regard getting full as nutriton $(5,6)$. Present study is aimed and conducted to determine dietary habits of university students.

\section{Materials and Methods}

In this descriptive study conducted to determine dietary habits of university students, general scanning method was used. Population of the study consists of 1532 first or second year students from Vocational School of Health, Faculty of 
Health Sciences, Faculty of Science and Letters (Physic Department) in Selcuk University. As reaching the whole population is economical, 310 students are included in sampling by using proportional cluster sampling method. Study is initiated after getting necessary permission from Selcuk University Faculty of Medicine ethical comittee. Data was collected in 2008-2009 education season through quessionnaire forms filled with face-to-face interview method. Questionnaire form consisted of 26 questions aimed to determine demograhic features and dietary habits of students. Students were asked to record their personal food consumption during one day in order to detect their daily energy and nutrients consumption. To calculate the amount of energy and nutrional value gained through consumed foods and drinks, "Compter Supported Nutrition Program, Nourishment Information System (BeBis-5) designed specially to Turkey was used (7). Data was compared to "daily energy and nutrional intake levels recommended for Turkey" (8). When evaluating, recommended daily intake levels $[(2 / 3=\% 67) \pm \% 33]$ were calculated as intersection points. Intake of those consuming $67-133 \%$ of recommended levels of energy and other nutrients was adequate; of those consuming $<67 \%$ was inadequate and of those consuming $>133 \%$ was excessive (9). For anthropometric measurements, students' body weight was measured by a 0.5 $\mathrm{kg}$ sensitive portable digital scale and their height was measured by standing feet together, head, buttocks and heels touching the wall in Frankfort horizantal plane (orbitales and the tragus are on the same line) $(9,10)$. Body Mass Index a method often used for assessment of obesity was calculated with the formula: BMI = kilo $(\mathrm{kg}) /$ height $2(\mathrm{~m})$. According to BMI values; $<18.5$ was accepted as underweight, 18.524.9 as normal, $\geq 25$ as overweight, $\geq 30$ as obesity (11). Collected data was statistically evaluated by SPSS 15.0 Program with chi-square test (X2), t test and Mann Whitney $\mathrm{U}$ test and statictical significance level was accepted as $\mathrm{p}<0.01$. However, $\mathrm{p}<0.05$ level was also referred when no difference was observed.

\section{Results and Discussion}

Table 1. Demographic Features of Students.

\begin{tabular}{lll}
\hline Features & $\mathbf{n = 3 1 0}$ & $\mathbf{\%}$ \\
\hline Gender & 185 & \\
Male & 125 & 59.7 \\
Female & & 40.3 \\
Faculty - School & 28 & \\
Fac. of Health Sciences & 130 & 9.0 \\
Fac. of Science and Letters & 152 & 41.9 \\
Vocational Sch of Health Sci. & & 49.1 \\
Socioeconomical Status & 21 & \\
Low & 260 & 6.8 \\
Middle & 29 & 83.9 \\
High & 9.3 \\
\hline
\end{tabular}

As it is seen in Table $1,59.7 \%$ of the participants were male and $40.3 \%$ were female. It is possible to say that a balance is established in terms of gender. The students participated in the study were randomly selected and the sample was formed from 1 st or 2 nd grade students. In terms of socioeconomic status, students evaluated themselves mostly $(83.9 \%)$ as middle level.

Table 2. Avarage Age, Height, Bodyweight, Monthly Income and Food Expenses of the Students $(n=310)$.

\begin{tabular}{ll}
\hline Features & $\bar{X}$ \\
\hline Age (year) & $21.9 \pm 3.72$ \\
Height $(\mathrm{cm})$ & $169.0 \pm 14.48$ \\
Bodyweight $(\mathrm{kg})$ & $65.1 \pm 12.91$ \\
Monthly income (TL) & $1621.6 \pm 1177.11$ \\
Monthly food expenses (TL) & $326.0 \pm 298.73$ \\
\hline
\end{tabular}

Students from 1621.6 TL monthly income families stated that they spend an avarage of $326 \mathrm{TL}$ per month for their personal nourishment (Table 2). Generally speaking, it can be said that students participated in the study are children of middle income families.

Table 3. Gender and BMI Groups of Students.

\begin{tabular}{|c|c|c|c|c|c|c|c|c|c|c|}
\hline \multirow{2}{*}{$\begin{array}{l}\text { BMI }\left(\mathrm{kg} / \mathrm{m}^{2}\right) \\
\text { Gender }\end{array}$} & \multicolumn{2}{|c|}{$<18.5$ Underweight } & \multicolumn{2}{|c|}{ 18.5 - 24.9 Normal } & \multicolumn{2}{|c|}{$\geq 25.0$ Overweight } & \multicolumn{2}{|l|}{ Total } & \multirow[t]{2}{*}{$\mathbf{X} 2$} & \multirow{2}{*}{$\mathbf{P}$} \\
\hline & $\mathbf{n}$ & $\%$ & $\mathbf{N}$ & $\%$ & $\mathbf{N}$ & $\%$ & $\mathbf{N}$ & $\%$ & & \\
\hline Male & 10 & 5.4 & 126 & 68.1 & 49 & 26.5 & 185 & 100.0 & & \\
\hline Female & 32 & 25.6 & 81 & 64.8 & 12 & 9.6 & 125 & 100.0 & 31.795 & $0.000^{*}$ \\
\hline Total & 42 & 13.5 & 207 & 66.8 & 61 & 19.7 & 310 & 100.0 & & \\
\hline
\end{tabular}

${ }^{*} \mathrm{p}<0.01$

According to BMI results, female students are mostly in underweight group (25.6\%) while male students are mostly in overweight group $(26.5 \%)$. The high rate of being overweight among male students is associated with physical inactivity. Besides, among normal weight group, the number of male students is more than the number of female students. There weren't any obese $(\geq 30.0)$ students (Table 3). Ortiz-Moncada et al., (2012) reported that underweight group consisted of more female students $(9.8 \%)$, while overweight group consisted of more male students (34.6\%) according to the BMI results of their study (12). In their study on university students, Gan et al., (2011) also found that $14.3 \%$ of male students and $22.4 \%$ of female students were underweight. $14.0 \%$ of men were overweight but the rate of being overweight was $12.3 \%$ for women (13). According to the research findings of Seidler and Szczuko (2009), average BMI of the students was at a rate of $66.6 \%$ - $69.8 \%$ and there were no obese students (14). Likewise, in a study on this topic $9.5 \%$ of the participant students were underweight, $77.9 \%$ were normal and $12.6 \%$ were 
overweight or obese (15). In parallel with these findings Avsar et al. (2013), stated that $76.5 \%$ of the students' body weight were "normal", $14.1 \%$ were "overweight" in terms of BMI and it was observed that almost all $(91.7 \%)$ of the overweight students consisted of male students (16). Similarly, another study indicated that $8.6 \%$ of the students were underweight $(\mathrm{BMI}<18.5), 20 \%$ were overweight or obese $(\mathrm{BMI}<25)$ and also male students $\left(24.01 \pm 3.17 \mathrm{~kg} / \mathrm{m}^{2}\right)$ were found more overweight than female students $(20.98 \pm 2.87 \mathrm{~kg} / \mathrm{m} 2)(17)$. These findings are consistent with a recent study conducted by Huda \& Ruzita (2010) on 264 male and 360 female students in Universiti Sains Malaysia which reported that $27.4 \%$ of the students $(32.8 \%$ females and $20.1 \%$ males) were underweight, $9.6 \%$ (6.1\% females and $14.4 \%$ males) were overweight and $1.8 \% \quad(0.6 \%$ females and $3.4 \%$ males) were obese (18).

Table 4. Places Where Students Mostly Consume Their Foods.

\begin{tabular}{lllllll}
\hline Place of meal & \multicolumn{2}{l}{ Morning } & Noon & \multicolumn{3}{l}{ Night } \\
\cline { 2 - 7 } consumption & $\mathbf{N}$ & $\mathbf{\%}$ & $\mathbf{n}$ & $\mathbf{\%}$ & $\mathbf{N}$ & $\mathbf{\%}$ \\
\hline At home & 157 & 50.6 & 64 & 20.6 & 192 & 61.0 \\
At school cafeteria & 18 & 5.8 & 41 & 13.2 & 19 & 6.1 \\
At Canteen & 61 & 19.7 & 87 & 28.1 & 10 & 3.2 \\
At school/bringing & 1 & 0.3 & 2 & 0.7 & 1 & 0.3 \\
from home & & & & & & \\
Out & 34 & 11.0 & 92 & 29.7 & 83 & 26.8 \\
Not eating & 39 & 12.6 & 24 & 7.7 & 5 & 1.6 \\
Total & 310 & 100.0 & 310 & 100.0 & 310 & 100.0 \\
\hline
\end{tabular}

Students eat their breakfast mostly at home (50.6\%), and canteen follows with a rate of $19.7 \%$. Students have their lunch mostly out $(29.7 \%)$ and at canteen with a rate of $\% 28.1$. They eat dinner mostly at home $(61.0 \%)$. Those who eat dinner out follow this with a rate of $26.8 \%$ (Table 4 ). The results of other studies are also similar in terms of place of eating a meal. It is revealed that students have their breakfast and dinner mainly at home and eat lunch outside home (1.16). Contrary to the present study, Ermis et al. (2015), discovered in their study that most frequently used places by students to eat main meal and snacks are "school, dormitory, canteen and school cafeteria" (53.6\%). "Home" (37.5) and "restaurant, café, bakery" (9\%) follow them. On the other hand, when snack variable is examined most popular place is "school, dormitory, canteen and school cafeteria" (69.2\%), second popular is "restaurant, café, bakery" $(22.8 \%)$ and the last is "home" (8\%) (19). Facilities related to time and socioecononic circumstances such as personal preferences, course schedule, place quality, house distance can be the reason of the difference between study findings.

Table 5. Skipping A Meal Situation of Students $(n=310)$.

\begin{tabular}{|c|c|c|c|c|c|c|}
\hline \multirow[t]{2}{*}{ Meals } & \multicolumn{2}{|c|}{$\begin{array}{l}\text { Usually skip the } \\
\text { meal }\end{array}$} & \multicolumn{2}{|c|}{$\begin{array}{l}\text { Sometimes skip } \\
\text { the meal }\end{array}$} & \multicolumn{2}{|c|}{ Total } \\
\hline & $\mathbf{N}$ & $\%$ & $\mathbf{N}$ & $\%$ & $\mathbf{N}$ & $\%$ \\
\hline Morning & 117 & 37.7 & 71 & 22.9 & 188 & 60.6 \\
\hline Noon & 81 & 26.1 & 52 & 16.8 & 133 & 42.9 \\
\hline Night & 14 & 4.5 & 12 & 3.8 & 26 & 8.3 \\
\hline
\end{tabular}

It is discovered that most of the participant students skip a meal and only $16.8 \%$ of them have three main meals. Breakfast is found to be the most skipped meal. $60.6 \%$ of the students stated that they either have no breakfast or sometimes skip this meal (Table 5). Among university students, skipping a meal is a mostly common habit (6).

Gan et al. (2011) reported in their study that most of the participants $(73.8 \%$ male and $74.6 \%$ female) skip at least a meal a day and the most skipped meal is breakfast (13). A similar tendency is reported in the study of Omidvar and Begum (2014). They also observed that $52.1 \%$ of adolescents and $49 \%$ of adults can skip breakfast a few times a week (20). In their study, Cetin and Sarper (2013) reported that $51.1 \%$ of the medical faculty first-year students and $60.4 \%$ of sixth-year students eat three meals a day. The rate of the students who stated that they have five and more meals is $8.6 \%$ for first-year and $5.0 \%$ for sixthyear students (21). In the study conducted by Shi, Lien, Kumar, and Holmboe-Ottesen (2005), it is found that $76 \%$ of the students regularly eat three meals a day, but $8.1 \%$ of those who live in the city and $3.4 \%$ of those who live in the country have breakfast once to three times a week or less (22). Findings of the study by Akcam Oluk et al., (2011) indicated that morning meal is the most $(44.0 \%)$, and night meal is the least $(2.0 \%)$ skipped meal (23). It is also seen in the study by Ayhan et al., (2012) that the most significant $(44.6 \%)$ main meal for the students is dinner $(\mathrm{p}<0.05)$ and breakfast was observed as the most skipped main meal $(58.2 \%)$ (16). The habit of eating breakfast regularly is linked to low blood cholesterol level and low body wieght (24). The study conducted by Ermis et al., (2015) indicated that the significance of breakfast, lunch and dinner for students are $58.1 \%, 14.9 \%$ and $27 \%$ respectively. Moreover, only one-fourth of the students $(23.9 \%)$ don't skip any meals but most students (76.1\%) stil skip a meal (19). According to the results of the study by Erten (2006), more than half of the students $(51.6 \%)$ eat three main meals, $42.0 \%$ of them eat two and $6.4 \%$ eat only one main meal. When their snack food consumption is examined, $43.6 \%$ of the students have a snack only once a day and $28.0 \%$ of the students skip snacks (1). Findings of the studies conducted by Ulas et al., (2013), Tumerdem et al., (1985), Vancelik et al., (2006) and Gulec et al. (2008), also support this study $(25,26,27,28)$. On the contrary breakfast is accepted as the most significant meal and it has $95 \%$ consumption rate in some European countries (29). Different findings of the studies reveal that skipping a meal is a commonly observed problem among university students. However, the students should be informed about that three meals should be consumed regularly to have a healthy and balanced diet and if they eat less or unbalanced, it will affect metabolism in a negative way (30). The reason why students skip a meal can be caused by the temporal, psychological and socioeconomic differences related to university life. 
Table 6. The Avarage amount of The Students' Energy and Nutrients Intake (daily) Based on Gend.

\begin{tabular}{|c|c|c|c|c|c|c|c|c|c|}
\hline \multirow{2}{*}{ Energy Nutrients } & \multirow{2}{*}{$\begin{array}{l}\text { Male } \\
(n=185)\end{array}$} & \multirow{2}{*}{$\begin{array}{l}\text { Female } \\
(n=125)\end{array}$} & \multirow{2}{*}{$\begin{array}{l}\text { Total } \\
(n=310)\end{array}$} & \multicolumn{2}{|c|}{ Levene's Test } & \multicolumn{2}{|l|}{ t test } & \multicolumn{2}{|c|}{ Mann Whitney U Test } \\
\hline & & & & $\mathbf{F}$ & $\mathbf{p}$ & $\mathbf{T}$ & $\mathbf{p}$ & MWU & $\mathbf{p}$ \\
\hline Energy (kcal) & $2075.9 \pm 965.85$ & $1681.6 \pm 865.36$ & $1878.7 \pm 936.55$ & 3.754 & .054 & 3.785 & $.000 * *$ & -- & -- \\
\hline Protein (g) & $72.4 \pm 41.36$ & $57.8 \pm 33.77$ & $65.1 \pm 38.39$ & 5.526 & $.019 *$ & -- & -- & 9327.0 & $.001^{* *}$ \\
\hline Protein $(\%)$ & $14.7 \pm 5.10$ & $14.4 \pm 4.62$ & $14.5 \pm 4.86$ & 1.598 & .207 & .583 & .560 & -- & -- \\
\hline Fat $(g)$ & $80.0 \pm 48.58$ & $70.3 \pm 49.46$ & $75.1 \pm 49.18$ & .006 & .938 & 1.741 & .083 & -- & -- \\
\hline Fat $(\%)$ & $34.6 \pm 9.88$ & $36.7 \pm 11.37$ & $35.6 \pm 10.68$ & 3.106 & .079 & -1.663 & .097 & -- & -- \\
\hline Saturated fat (g) & $24.8 \pm 16.06$ & $22.2 \pm 17.26$ & $23.5 \pm 16.69$ & .657 & .418 & 1.356 & .176 & -- & -- \\
\hline $\begin{array}{l}\text { Monounsaturated fatty } \\
\text { acid (g) }\end{array}$ & $24.9 \pm 15.00$ & $21.5 \pm 14.72$ & $23.2 \pm 14.94$ & .963 & .327 & 2.050 & $.041 *$ & -- & -- \\
\hline $\begin{array}{l}\text { Polysaturated fatty } \\
\text { acid (g) }\end{array}$ & $24.8 \pm 20.86$ & $21.9 \pm 18.95$ & $23.3 \pm 19.95$ & .038 & .846 & 1.276 & .203 & -- & -- \\
\hline Cholesterol (mg) & $217.4 \pm 185.46$ & $153.1 \pm 130.52$ & $185.3 \pm 163.31$ & 13.798 & $.000 * *$ & -- & -- & 9715.5 & $.004 * *$ \\
\hline Carbohydrate (\%) & $50.5 \pm 9.46$ & $48.9 \pm 10.96$ & $49.7 \pm 10.25$ & 4.083 & $.044 *$ & -- & -- & 10568.5 & .067 \\
\hline Posa (g) & $19.8 \pm 11.54$ & $17.6 \pm 8.74$ & $18.7 \pm 10.28$ & 6.266 & $.013 *$ & -- & -- & 11025.0 & .211 \\
\hline Water soluble pulp (g) & $6.3 \pm 3.60$ & $5.3 \pm 2.75$ & $5.8 \pm 3.24$ & 8.672 & $.003 *$ & -- & -- & 10148.0 & .018 \\
\hline $\begin{array}{l}\text { Water nonsoluble } \\
\text { pulp }(g)\end{array}$ & $12.8 \pm 7.70$ & $11.0 \pm 5.74$ & $11.9 \pm 6.84$ & 5.360 & $.021 *$ & -- & -- & 10623.5 & .078 \\
\hline Vitamin A(RE mcg) & $1282.6 \pm 2200.04$ & $1130.6 \pm 1286.03$ & $1206.6 \pm 1800.64$ & 1.849 & .175 & .742 & .458 & -- & -- \\
\hline Carotene (mg) & $1.8 \pm 1.51$ & $2.2 \pm 2.34$ & $2.0 \pm 1.97$ & 12.916 & $.000 * *$ & -- & -- & 11717.0 & .708 \\
\hline Vitamin E (mg) & $20.0 \pm 14.70$ & $17.2 \pm 14.47$ & $18.6 \pm 14.63$ & .182 & .670 & 1.678 & .094 & -- & -- \\
\hline Vitamin $\mathrm{B}_{1}$ (mg) & $.7 \pm .37$ & $.6 \pm .32$ & $.7 \pm .35$ & 3.165 & .076 & 2.539 & $.012 *$ & -- & -- \\
\hline Vitamin $\mathrm{B}_{2}(\mathrm{mg})$ & $1.2 \pm .70$ & $1.0 \pm .57$ & $1.1 \pm .65$ & 5.742 & $.017 *$ & -- & -- & 9253.5 & $.000^{* *}$ \\
\hline Vitamin $\mathrm{B}_{6}(\mathrm{mg})$ & $1.1 \pm .64$ & $1.0 \pm .59$ & $1.0 \pm .62$ & 2.797 & .095 & 1.774 & .077 & -- & -- \\
\hline Pantothenic acid (mg) & $4.1 \pm 2.12$ & $3.4 \pm 1.83$ & $3.7 \pm 2.01$ & 4.854 & $.028 *$ & -- & -- & 9545.0 & $.002 * *$ \\
\hline Niasin (mg) & $9.3 \pm 5.73$ & $8.5 \pm 6.20$ & $8.9 \pm 5.98$ & .644 & .423 & 1.199 & .231 & -- & -- \\
\hline Folate (mcg) & $114.0 \pm 61.64$ & $95.1 \pm 49.94$ & $104.5 \pm 56.80$ & 5.122 & $.024 *$ & -- & -- & 9962.5 & $.009 * *$ \\
\hline Vitamin C (mg) & $105.5 \pm 109.06$ & $91.5 \pm 79.84$ & $98.5 \pm 95.68$ & 5.111 & $.024 *$ & -- & -- & 11654.5 & .650 \\
\hline Vitamin D (mcg) & $1.2 \pm 1.58$ & $1.2 \pm 3.75$ & $1.2 \pm 2.87$ & .046 & .830 & -.023 & .982 & -- & -- \\
\hline Vitamin K (mcg) & $305.0 \pm 243.97$ & $260.7 \pm 186.95$ & $282.9 \pm 218.12$ & 3.366 & .068 & 1.797 & .073 & -- & -- \\
\hline Sodium (mg) & $2233.1 \pm 1445.25$ & $1867.6 \pm 1222.12$ & $2050.3 \pm 1348.65$ & 6.100 & $.014^{*}$ & -- & -- & 10113.5 & $.016^{*}$ \\
\hline Potasium (mg) & $2094.5 \pm 1168.79$ & $1918.6 \pm 1016.61$ & $2006.6 \pm 1097.12$ & 2.328 & .128 & 1.414 & .158 & -- & -- \\
\hline Calsium (mg) & $622.7 \pm 381.26$ & $553.4 \pm 357.73$ & $588.0 \pm 370.71$ & 1.630 & .203 & 1.650 & .100 & -- & -- \\
\hline Magnesium (mg) & $239.9 \pm 268.08$ & $216.4 \pm 162.74$ & $228.1 \pm 221.71$ & .659 & .418 & .934 & .351 & -- & -- \\
\hline Phosphor (mg) & $1124.6 \pm 702.59$ & $943.7 \pm 508.17$ & $1034.1 \pm 618.81$ & 3.539 & .061 & 2.597 & $.010^{*}$ & -- & -- \\
\hline Iron (mg) & $12.0 \pm 9.57$ & $10.0 \pm 6.25$ & $11.0 \pm 8.13$ & 1.644 & .201 & 2.204 & $.028 *$ & -- & -- \\
\hline Zinc (mg) & $11.3 \pm 8.13$ & $8.6 \pm 5.30$ & $10.0 \pm 6.99$ & 8.564 & $.004 *$ & -- & -- & 9393.0 & $.001^{* *}$ \\
\hline Iodine (mcg) & $40.5 \pm 24.46$ & $39.1 \pm 26.14$ & $39.8 \pm 25.28$ & .051 & .822 & .501 & .617 & -- & -- \\
\hline Nutritional Water (g) & $1225.8 \pm 781.13$ & $1057.0 \pm 564.77$ & $1141.4 \pm 685.72$ & 3.738 & .054 & 2.180 & $.030 *$ & -- & -- \\
\hline Drunk Water (g) & $1114.9 \pm 1040.67$ & $1063.6 \pm 969,08$ & $1089.2 \pm 1004.21$ & 1.771 & .184 & .449 & .654 & -- & -- \\
\hline
\end{tabular}

$* * \mathrm{p}<0.01 * \mathrm{p}<0.05$

Avarage amount of daily energy and nutrients intake based on gender of the study population has been counted as $2075.9 \pm 965.85 \mathrm{kcal} / \mathrm{day}$ for male students and $1681.6 \pm 865.36 \mathrm{kcal} /$ day for female students. As a result of the statistical comparision, it is found, as expected, that male students have significantly $(\mathrm{p}<0.01)$ more daily energy than female students have. Apart from protein $(\mathrm{g})$, the difference among $\mathrm{B}_{12}$ vitamin, biotin, carbohydrate $(\mathrm{g}), \mathrm{B}_{2}$ vitamini and 
zinc, pantothenic acid, folate $(\mathrm{p}<0.01) ; \mathrm{B}_{1}$, iron and phosphorus $(\mathrm{p}<0.05)$ consumption based on gender was found statistically significant (Table 6). In a research on young people, Yayc1 et al. (1993) determined that male students have average $1870 \pm 670 \mathrm{kcal}$ and female students have average $1422 \pm 558 \mathrm{kcal}$ energy a day (31). In a study on Chinese adults, Karim (2000) reported that avarage daily energy intake was calculated as $2105 \pm 418 \mathrm{kcal}$ for males and $1530 \pm 373 \mathrm{kcal}$ for females (32).

The study on university students by Glodek and Gil (2012) indicated that avarage daily energy intake was $2283,22 \mathrm{kcal} /$ day for male students and 1568,56 kcal / day for female students (33). Gan et al. (2011) stated in their study that avarage daily energy intake for male and female students was $2120 \pm 614 \mathrm{kcal}$ and $1624 \pm 506 \mathrm{kcal}$, respectively (13). González Carrascosa et al. (2011) calculated avarage daily energy intake as $2,077 \mathrm{kcal} /$ day for male students and 1.635 $\mathrm{kcal} /$ day for female students in their study (34). Findings of the studies conducted in other countries are also similar to those results. When this study is compared to the study by Duman (2007), it can be seen that male students' energy intake amount is similar $(2578 \pm 656.9 \mathrm{kcal})(35)$. In their study, Bas et al. (2005) reported that energy intake amount of females and males aged 12-19 are calculated as $1964 \pm 723$ $\mathrm{kcal}$ and $1804 \pm 486 \mathrm{kcal}$, respectively (36). When the results are compared to the study by Bas et al. (2005), it can be seen that energy intake of female adoescents is similar to the present study but energy intake of male adolescents is higher. According to the study by Yabanc1 (2004), energy intake of males is $2360.5 \pm 806.4 \mathrm{kcal} /$ day and energy intake of females is $2249.8 \pm 823.1 \mathrm{kcal} /$ day (37). When this study is examined, it is seen that energy intake for males is similar to the present study, but the amount for females is quite higher. In his study, Gumus (2009) repoted that daily energy intake by diet is $1837.1 \pm 461.09 \mathrm{kcal} /$ day for male students and 1154.5 \pm $361.48 \mathrm{kcal} /$ day for female students. It is seen that energy intake of males are quite higher than females students' and this difference is found statistically significant $(\mathrm{p}<0001)$ (38). When compared to the study by Gumus (2009), energy intake by diet is found inadequate both for males and females in the present study (38). As the necessary calorie amount that university students should spend is regarded same as the amount for workers with a job requiring moderate workforce, students' calorie intake is under the desired level.

Table 7. Evaluation of Students' Daily Energy and Nutrients Consumption Based on Gender according to RDA.

\begin{tabular}{|c|c|c|c|c|c|c|c|c|c|}
\hline \multirow{2}{*}{ Nutrient } & \multirow{2}{*}{ Gender } & \multicolumn{2}{|c|}{ Inadequate } & \multicolumn{2}{|c|}{ Adequate } & \multicolumn{2}{|c|}{ Excessive } & \multirow{2}{*}{$\mathbf{X} 2$} & \multirow{2}{*}{$\mathbf{p}$} \\
\hline & & $\mathbf{N}$ & $\%$ & $\mathbf{n}$ & $\%$ & $\mathbf{n}$ & $\%$ & & \\
\hline \multirow{3}{*}{$\begin{array}{l}\text { Energy } \\
\text { (kcal) }\end{array}$} & Male & 71 & 45.8 & 79 & 51.0 & 5 & 3.2 & \multirow{3}{*}{2.487} & \multirow{3}{*}{0.288} \\
\hline & Female & 71 & 45.8 & 73 & 47.1 & 11 & 7.1 & & \\
\hline & Total & 142 & 45.8 & 152 & 49.0 & 16 & 5.2 & & \\
\hline \multirow{3}{*}{ Protein (g) } & Male & 29 & 18.7 & 61 & 39.4 & 65 & 41.9 & \multirow{3}{*}{0.083} & \multirow{3}{*}{0.960} \\
\hline & Female & 31 & 20.0 & 60 & 38.7 & 64 & 41.3 & & \\
\hline & Total & 60 & 19.4 & 121 & 39.0 & 129 & 41.6 & & \\
\hline \multirow{3}{*}{$\begin{array}{l}\text { A vit. } \\
\text { (RE } \mathrm{mcg} \text { ) }\end{array}$} & Male & 78 & 50.3 & 42 & 27.1 & 35 & 22.6 & \multirow{3}{*}{4.863} & \multirow{3}{*}{0.088} \\
\hline & Female & 60 & 38.7 & 46 & 29.7 & 49 & 31.6 & & \\
\hline & Total & 138 & 44.5 & 88 & 28.4 & 84 & 27.1 & & \\
\hline \multirow{3}{*}{$\begin{array}{l}\text { E vit. } \\
\text { (mg) }\end{array}$} & Male & 48 & 31.0 & 39 & 25.2 & 68 & 43.9 & \multirow{3}{*}{3.308} & \multirow{3}{*}{0.191} \\
\hline & Female & 63 & 40.6 & 36 & 23.2 & 56 & 36.1 & & \\
\hline & Total & 111 & 35.8 & 75 & 24.2 & 124 & 40.0 & & \\
\hline \multirow{3}{*}{$\begin{array}{l}\text { K vit. } \\
\text { (mg) }\end{array}$} & Male & 20 & 12.9 & 23 & 14.8 & 112 & 72.3 & \multirow{3}{*}{0.565} & \multirow{3}{*}{0.777} \\
\hline & Female & 16 & 10.3 & 24 & 15.5 & 115 & 74.2 & & \\
\hline & Total & 36 & 11.6 & 47 & 15.2 & 227 & 73.2 & & \\
\hline \multirow{3}{*}{$\begin{array}{l}\mathrm{B}_{2} \text { vit. } \\
(\mathrm{mg})\end{array}$} & Male & 55 & 35.5 & 69 & 44.5 & 31 & 20.0 & \multirow{3}{*}{1.118} & \multirow{3}{*}{0.572} \\
\hline & Female & 53 & 34.2 & 77 & 49.7 & 25 & 16.1 & & \\
\hline & Total & 108 & 34.8 & 146 & 47.1 & 56 & 18.1 & & \\
\hline \multirow{3}{*}{$\begin{array}{l}\text { Niasin } \\
(\mathrm{mg})\end{array}$} & Male & 97 & 62.6 & 53 & 34.2 & 5 & 3.2 & \multirow{3}{*}{1.268} & \multirow{3}{*}{0.530} \\
\hline & Female & 101 & 63.2 & 46 & 29.7 & 8 & 5.2 & & \\
\hline & Total & 198 & 63.9 & 99 & 31.9 & 13 & 4.2 & & \\
\hline \multirow{3}{*}{$\begin{array}{l}\text { B }_{6} \text { vit. } \\
(\mathrm{mg})\end{array}$} & Male & 61 & 39.4 & 62 & 40.0 & 32 & 20.6 & \multirow{3}{*}{5.875} & \multirow{3}{*}{0.053} \\
\hline & Female & 74 & 47.7 & 64 & 41.3 & 17 & 11.0 & & \\
\hline & Total & 135 & 43.5 & 126 & 40.6 & 49 & 15.8 & & \\
\hline
\end{tabular}


Table 7. Cont.

\begin{tabular}{|c|c|c|c|c|c|c|c|c|c|}
\hline \multirow{2}{*}{ Nutrient } & \multirow[b]{2}{*}{ Gender } & \multicolumn{2}{|c|}{ Inadequate } & \multicolumn{2}{|c|}{ Adequate } & \multicolumn{2}{|c|}{ Excessive } & \multirow{2}{*}{$\mathrm{X} 2$} & \multirow{2}{*}{$\mathbf{P}$} \\
\hline & & $\mathbf{N}$ & $\%$ & $\mathbf{n}$ & $\%$ & $\mathbf{n}$ & $\%$ & & \\
\hline \multirow{3}{*}{$\begin{array}{l}\text { Folat } \\
(\mathrm{mcg})\end{array}$} & Male & 151 & 97.4 & 4 & 2.6 & -- & -- & & \\
\hline & Female & 155 & 100.0 & -- & -- & -- & -- & -- & -- \\
\hline & Total & 306 & 98.7 & 4 & 1.3 & -- & -- & & \\
\hline \multirow{3}{*}{$\begin{array}{l}B_{12} \text { vit. } \\
\text { (mg) }\end{array}$} & Male & 59 & 38.1 & 94 & 60.6 & 2 & 1.3 & & \\
\hline & Female & 81 & 52.3 & 33 & 21.3 & 41 & 26.5 & 75.225 & $0.000 *$ \\
\hline & Total & 140 & 45.2 & 127 & 40.9 & 43 & 13.9 & & \\
\hline \multirow{3}{*}{ C vit. (mg) } & Male & 64 & 41.3 & 43 & 27.7 & 48 & 31.0 & & \\
\hline & Female & 60 & 38.7 & 43 & 27.7 & 52 & 33.5 & 0.289 & 0.865 \\
\hline & Total & 124 & 40.0 & 86 & 27.7 & 100 & 32.3 & & \\
\hline \multirow{3}{*}{$\begin{array}{l}\text { Calsium } \\
(\mathrm{mg})\end{array}$} & Male & 99 & 63.9 & 49 & 31.6 & 7 & 4.5 & & \\
\hline & Female & 115 & 74.2 & 37 & 23.9 & 3 & 1.9 & 4.471 & 0.107 \\
\hline & Total & 214 & 69.0 & 86 & 27.7 & 10 & 3.2 & & \\
\hline \multirow{3}{*}{$\begin{array}{l}\text { Phosphor } \\
\text { (mg) }\end{array}$} & Male & 13 & 8.4 & 60 & 38.7 & 82 & 52.9 & & \\
\hline & Female & 20 & 12.9 & 65 & 41.9 & 70 & 45.2 & 2.632 & 0.268 \\
\hline & Total & 33 & 10.6 & 125 & 40.4 & 152 & 49.0 & & \\
\hline \multirow{3}{*}{$\begin{array}{l}\text { Magnesium } \\
(\mathrm{mg})\end{array}$} & Male & 118 & 76.1 & 31 & 20.0 & 6 & 3.9 & & \\
\hline & Female & 94 & 60.6 & 47 & 30.3 & 14 & 9.0 & 9.199 & 0.011 ** \\
\hline & Total & 212 & 68.4 & 78 & 25.2 & 20 & 6.5 & & \\
\hline \multirow{3}{*}{$\begin{array}{l}\text { Iron } \\
(\mathrm{mg})\end{array}$} & Male & 22 & 14.2 & 59 & 38.1 & 74 & 47.7 & & \\
\hline & Female & 114 & 73.5 & 37 & 23.9 & 4 & 2.6 & 130.097 & $0.000^{*}$ \\
\hline & Total & 136 & 43.9 & 96 & 31.0 & 78 & 25.2 & & \\
\hline \multirow{3}{*}{$\begin{array}{l}\text { Zinc } \\
(\mathrm{mg})\end{array}$} & Male & 58 & 37.4 & 58 & 37.4 & 39 & 25.2 & & \\
\hline & Female & 45 & 29.0 & 64 & 41.3 & 46 & 29.7 & 2.512 & 0.285 \\
\hline & Total & 103 & 33.2 & 122 & 39.4 & 85 & 27.4 & & \\
\hline
\end{tabular}

$* \mathrm{p}<0.01 * * \mathrm{p}<0.05$

Vitamin $\mathrm{K}$ and phosphorus intake of the students in the sampling is found to exceed the 2/3 RDA values. According to RDA, $\mathrm{K}$ vitamin intake for both groups is more $(73.2 \%)$ than the usual amount. Vitamin $\mathrm{K}$ deficiency is not common among people. It is known that more than half of the vitamin $\mathrm{K}$ amount in human body is provided from the intestines. It is also found in many animal and vegetative foods. In relation to purchasing power, students consume green leafy vegetables, legumes, tea and coffee which are rich in vitamin $\mathrm{K}$ (39). Generally speaking, some inequalties in certain nutrients use between genders are determined, especially niacin, folate, calcium, iron (for females) and magnesium deficiency is observed (Table 7). Iron deficiency can be related to the fact taht cereal is the main meal. Folic acid (folate) deficiency causes abnormal DNA synthesis. Thus blood cells are negatively affected in case of its deficiency. Pregnant women can develop Spina Bifida (split spine) in folic acid deficiency. Thus female students with inadequate folic acid intake are under a risk of having disabled baby. In the study by Pinto (2015), female students aged between 19 and 25 are observed to have quite inadequate folate intake (40). According to the result of their study, Seidler and Szczuko (2009) stated that students' vitamin D, copper, calcium and fibre intake is low (22\%-63.4\%) but sodium, phosphorus, vitamin A and B12 intake is excessive (143.6\%481\%) according to RDA (14). Besides, Gumus (2009) reported that $4.3 \%$ of male adolescents and $32.5 \%$ of female adolescents diet is inadequate in terms of iron component
(38). Alanyalı (1990) conducted a research on adolescents and found that $40.5 \%$ of females and $15.7 \%$ of males were anemic. Iron intake of females was also found under the required daily level (41). In present study and Gumus's study (2009), calcium intake was inadequate for all of the participant adolescents $(100 \%)$. In face-to-face interviews with students, it is determined that they don't drink milk daily and they consume other dairy products little or sometimes owing to financial causes (38). Cetinkaya (2010) reported that $25 \%$ of students drink a glass of milk, $5 \%$ two glasses, $3 \%$ three glasses and $67 \%$ of them don't drink milk (42).

\section{Conclusion}

Guidance and councelling is considered as useful to provide adequate and balanced nutrition, improve, develop or extend nutrition facilities in universities and dormitories. This study is conducted to determine dietary habits of university students aged 17-35. According to the result of the study, $59.7 \%$ of the participants are male and $40.3 \%$ are female. Thus a balance is provided in terms of gender. The difference between BMI average values of the two genders is found significant $(p<0.01)$. None of the students is obese $(\geq 30.0)$. It is discovered that most of the students skip meals, only $16.8 \%$ of them eat three meals a day and breakfast is the most skipped meal $(60.6 \%)$. Also it is revealed that dinner is regularly consumed and not skipped. 
Among the three meals, breakfast and dinner is mostly consumed at home, lunch is consumed generally outside home. Avarage amount of daily energy and nutrients intake based on gender of the study population has been counted as $2075.9 \pm 965.85 \mathrm{kcal} /$ day for male students and $1681.6 \pm 865.36 \mathrm{kcal} /$ day for female students. By means of statistical comparision, it is found, as expected, that male students have significantly $(\mathrm{p}<0.01)$ more daily energy than female students have. Based on gender, the difference was found statistically significant between the intakes of vitamin B12, biotin, carbohydrate (g), vitamin B2 and zinc, pantothenic acid, folate $(\mathrm{p}<0.01), \mathrm{B} 1$, iron and phosphor $(\mathrm{p}<0.05)$ as well as protein $(\mathrm{g})$. When RDA values are taken into consideration, it is seen that calorie intake levels of the students are under the desired levels. In respect to these findings, dietary habits and knowledge of university students should be research at certain intervals should be researched, studies should be conducted to enrich dietary variety in menus of dormitories, school cafeterias and canteens. To provide adequate and balanced nutrition among the youth, it is recommended that healthy food consumption should be increased and further studies should be conducted on the factors determining the food selection.

\section{Acknowledgements}

The abstract of this study was displayed as a poster presentation at 11th Food Congress dated 10-12 October 2012 in Hatay, Turkey. In the study, the doctorate thesis by Gulcin ALGAN titled "Fruit Consumption among University Students and the Relationship between Fruit Consumption and Sour or Sweet Taste Preferences" was referred as a primary source.

\section{References}

[1] Erten, M. "A Research on Dietary Knowledge and Habits of University Students Studying in Adiyaman". Unpublished Postgraduate Thesis. Gazi University, Institute of Educational Sciences, Department of Household Economy and Nutrition Education, 2006, Ankara, Turkey.

[2] Baltac1, G., Ersoy, G., Karaagaoglu, N., Derman, O., Kanbur, N. "Ergenlerde Saglıklı Beslenme, Hareketli Yasam". 1st Edition Sinem Publishing, 2006, Ankara, Turkey.

[3] Deliens, T. Clarysa, P. Van Heckea, L. De Bourdeaudhuij, I. Deforchea, B. Changes in weight and body composition during the first semester at university. A prospective explanatory study. Appetite, Volume 65, 1 June 2013, Pages 111-116. doi:10.1016/j.appet.2013.01.024.

[4] Ross, J. Schweitzer, A. Klein, C. Mackey, E. and Lei, D.. "Validation of ALIVE Block Food Frequency Questionnaire for Use with College Students". The FASEB Journal, April, 2015, vol. 29 no. 1 Supplement 584.4.

[5] Karaoglu L, Pehlivan E, Genc MF, Gunes G, Egri M. "Dietary habits and physical activity levels of İnonu University second grade students". Health and society. 2005; 15: 82-88.
[6] Yaman, M, Yabancı N. "Evaluation of university students' dietary habits". Ist International Household Economy Congress, March 2006, Ankara. Congress Abstract Book, 214223pp.

[7] BEBİS. Ebispro Fur Windows, Stuttgart, Germany; Turkish Version (Bebis-5), 2004, İstanbul, Turkey.

[8] Baysal, A. "Beden Agırlıgının Denetimi Diyet El Kitabı". (Ed. A Baysal, N Bozkurt, G Pekcan, H.T. Besler, M Aksoy, T.K. Merdol, S Kececioglu, S.M. Mercanligil). 4th Edition, Hatipoglu Publishing House, Ankara, 2008, 22-23pp. Turkey.

[9] Pekcan G. "Hastanın Beslenme Durumunun Saptanması". In: Baysal A, Aksoy M, Bozkut M (eds). Diet Handbook. Ankara: Hatiboglu Publishing house, Ankara, 2002, 65-116pp. Turkey.

[10] Lee, R.D., Nieman, D.C. "Nutritional Assesment", The Macgraw-Hill Companies. 2003, Newyork.

[11] Gibson, E.L. "Principles of Nutritional Assesment". 1990, Newyork: Oxford Universty Press.

[12] R. Ortiz-Moncada, A. I. Norte Navarro, A. Zaragoza Marti, J. Fernández Sáez, M. a C. Davó Blanes. "Siguen patrones de dieta mediterránea los universitarios españoles? Do the Spanish university students follow Mediterranean dietary patterns?" Nutrición Hospitalaria, 2012, vol 27, Iss 6, Pp 1952-1959.

[13] Gan WY, Mohd Nasir MT, Zalilah MS \& Hazizi AS. "Differences in Eating Behaviours, Dietary Intake and Body Weight Status between Male and Female Malaysian University Students”. Mal J Nutr., 2011, 17 (2): 213-228.

[14] Seidler $\mathrm{T}^{1}$, Szczuko M. "Nutrition mode evaluation among University of Agriculture students in Szczecin in 2006. Part I. Consumption of selected nutrients and nourishment state". Rocz Panstw Zakl Hig. 2009; 60 (1): 59-64.

[15] Tutuncu, İ. Karaismailoglu, E. "Determining the knowledge levels of university students on nutrition". SSTB Journal Year: 2013 1ssue: 6 Subject: Nutrition and Dietetics

[16] Avsar, P. Kazan EE. Pınar G. "Research on eatıng habits of university students with risk factors related to obesity and chronıc diseases". Yıldırım Beyazıt University Faculty of Health Sciences Nursing E- Journal, volume 1 issue: 1, 2013.

[17] Ayhan, De. Gunaydın, E. Gonluacık. Arslan, U. Cetinkaya, F. Asimı, H. Uncu, Y. "The Characteristics and Related Factors of The Students' of Uludag University Medical Faculty". Journal of Uludag University Medical Faculty., 2012, 38 (2): 97-104.

[18] Huda N \& Ruzita A "Preliminary survey on nutritional status among university students at Malaysia". Pakistan J Nutr., 2010, $9(2): 125-127$.

[19] Ermis, E., Dogan, E., Erilli, N.A. \& Satıc1, A. "An examination of nutritional habits of university students: the model of Ondokuz Mayıs University". Journal of sports and performance researches, 2015, vol. 6, No.1.

[20] Omidvar, S and Begum, K. "Dietary pattern, food habits and preferences among adolescent and adult student girls from an urban area, South India". Indian Journal of Fundamental and Applied Life Sciences ISSN: 2231-6345 (Online) An Open Access, Online International Journal Available at http://www. cibtech.org/jls. Htm 2014 vol. 4 (2) April-June, pp. 465-473. 
[21] Cetin G. Sarper F. “A Study into The Nutrition Knowledge And Habits Of The First and Last Grade Students Of The Faculty Of Medicine". Education and Society in 21 st century volume 2 issue 6 Winter 2013

[22] Shi, Z., Lien, N., Kumar, B.N. and Holmboe-Ottesen, G. Socio-Demographic Differences in Food Habits and Preferences of School Adolescents in Jiangsu Province China. European Journal of Clinical Nutrition, 2005, 59 (12): 1439144.

[23] Akcam Oluk, E., Oluk, S., Davaslioglu, E.N. "Meal layout of aegean university students and edible beans consumption". C.B.U. Journal of Science 2011, 41-50.

[24] Ruxton CHS and Kirk TR. "Breakfast: a review of associations with measures of dietary intake, physiology and biochemistry". British Journal of Nutrition. 1997, 78 (2) 199214.

[25] Ulas, B., Uncu, F., Uner, S. "Prevalence and Affecting Factors of Potential Eating Disorders Among Students of Health Higher Education", İnonu University Journal of Health Sciences 2013; 2: 15-22.

[26] Tumerdem, Y., Ayhan, B., Coskun, A. "Nutritional Status of University Youth in A Metropolian City". Diabetes Annual; 1985, 4: 210-218.

[27] Vancelik, S., Onal Gursal, S., Guraksın, A. "Bodyweight Status and Some Related Factors among Students of Ataturk University". TAF Preventive Medicine Bulletin, 2006, 5 (2): 72-82.

[28] Gulec, M., Yabancı, N., Gocgelgi, E., Bakır, B. "Nutritional Habits of Students Living in Two Female Dormitories in Ankara”. Gulhane Journal of Medicine, 2008, 50: 102-109.

[29] Cavadini C, Decarli B, Grin J, Narring F and Michaud P-A. "Food habits and sport activity during adolescence: differences between athletic and non-athletic teenagers in Switzerland". European Journal of Clinical Nutrition 2000, 54 (Suppl 1) S16-S20.

[30] Tai MM, Castillo PP, Pi- Sunyer FX. "Meal size and frequency: Effect on the thermic Effect of food". Am J Clin Nutr. 1991; 54 (5): 783-787.

[31] Yayc1, M., Civi, S., Bediz, C. "Gençlerde Beslenme Alışkanlıkları. 3rd Community Health Days”. Kayseri: 96. 1993, Turkey.

[32] Karim, N. "Evaluation of nutritional status among A group of young chinese adults in Kuala Lumpur", Malaysia. Asia Pacific J Clin Nutr; 2000, 9 (2): 82-86.
[33] Głodek E ${ }^{1}$, Gil M. "Evaluation of the nutrition model in students of university in Rzeszow". Rocz Panstw Zakl Hig. 2012; 63 (3): 313-7.

[34] González Carrascosa $\mathrm{R}^{1}$, García Segovia P, Martínez Monzó J. Paper and pencil vs online self-administered food frequency questionnaire (FFQ) applied to university population: a pilot study. Nutr Hosp. 2011 Nov-Dec; 26 (6):1378-84. doi: $10.1590 / \mathrm{S} 0212-16112011000600027$.

[35] Duman, D. "Nutritional Status and Affecting Factors Of Adolescents Living in a Male Orphanage in Ankara Hacettepe University", Institute of Health Sciences, Nutrition and Dietetic Program, Unpublished Postgraduta Thesis, 2007, Ankara, Turkey.

[36] Bas, M., Altan, T., Dincer, T., Aran, E., Kaya, H. G. "Yuksek, O. Determination of dietary habits as a risk factor of cardiovascular heart disease in turkish adolescents". Eur. J. Nutr. Mar; 2005, 44 (3): 174-182.

[37] Yabanc1, N. "Detecting Growth And Obesity Status in SchoolAge Children And Assessment of Effecting Factors", Hacettepe University, Institute of Health Sciences, Nutrition and Dietetic Program, Unpublished Doctorate Thesis, 2004, Ankara, Turkey.

[38] Gumus, H. "Determining the relationship between Nutritional Status, Physical Activities and Health, Body Compositions of Adolescents Living in Orphanages". Gazi University, Institute of Educational Sciences, Department of Household Economy and Nutrition Education, Unpublished Doctorate Thesis, 2009, Ankara, Turkey.

[39] Baysal, A. Beslenme. Hatipoglu Publishing House, 2004, Ankara, Turkey.

[40] Pinto, P. "Folate intake in a Portuguese female student population and its relation to body mass index, physical activity level and intake of other nutrients". Mediterranean Journal of Nutrition and Metabolism 8 (2015): 75-83 doi:10.3233/MNM-150031.

[41] Alanyal1, M. "Examining Of 13-18 year-old Female and Male Groups Living in Orphanages in terms of Nutrition and Growth development", Hacettepe University, Community Healt Program, Unpublished Postgraduate Thesis, 1990, Ankara, Turkey.

[42] Cetinkaya A. "A Survey of the Consumption Habits of Milk and Milk Products among the Students in Kafkas University", Ataturk University Vet. Sci. Journal., 5 (2): 73-84, 2010. 